\title{
高出力・高輝度レーザを用いたステンレス鋼及びアルミニウム合金の 部分溶込み溶接における減圧雰囲気の影響*
}

\author{
阿部 洋平**, 川人 洋介***, 中村 浩****, 西本 浩司*****, 水谷 正海***, 片山 聖二 $* * *$ \\ Effect of Reduced Pressure Atmosphere on Partial Penetration Welds of Stainless Steel and \\ Aluminum Alloy with High Power and High Brightness Laser*
by ABE Youhei**, KAWAHITO Yousuke ${ }^{* * *}$, NAKAMURA Hiroshi****, NISHIMOTO Koji*****,
MIZUTANI Masami*** and KATAYAMA Seiji***

\begin{abstract}
Deep penetration is an important advantage in laser welding. This study was undertaken in order to investigate effect of reduced-pressure atmosphere from $0.1 \mathrm{kPa}$ to ambient pressure $(101 \mathrm{kPa})$ on partial penetration welding. A $16 \mathrm{~kW}$ disk laser of $1030 \mathrm{~nm}$ in wavelength was employed and Type 304 stainless steel and A5052 aluminum alloy was met-run welded in 17-mm/s welding speed. The penetration depths of the stainless steel and the aluminum alloy achieved 26 and $23 \mathrm{~mm}$, respectively, at vacuum pressure of $10 \mathrm{kPa}$. The depths were over 1.6 times as deep as those obtained at $101 \mathrm{kPa}$. Decrease of boiling temperature calculated on the basis of the reduced-pressure atmosphere coincided with an increase of the penetration depth. At less than $1 \mathrm{kPa}$, however, the penetration depth in steel was kept $26 \mathrm{~mm}$ steady and it in aluminum decreased to $19 \mathrm{~mm}$. Refraction angle caused by a laser-induced plume measured with a $532 \mathrm{~nm}$-wavelength probe laser beam was drastically reduced corresponding to surrounding pressure of 101 to $0.1 \mathrm{kPa}$. According to observation of the keyhole inlet with high-speed video camera, its size in steel decreased and stabilized with the pressure reduction, which indicate that reduced-pressure atmosphere made an incident laser beam focused stably with little influence of the plume and led to the stable keyhole inlet. On the other hand, the keyhole inlet in aluminum expanded more than quadruple of the ambient-pressure inlet size at 1 and $0.1 \mathrm{kPa}$, which seems to make such an unstable process that the weld penetration was reduced.
\end{abstract}

Key Words: disk laser, stainless steel, aluminum alloy, reduced-pressure atmosphere, penetration depth, laser-induced plume, keyhole inlet.

\section{1. 緒}

\section{言}

深溶込みはレーザ溶接の長所である.近年開発された高出 力・高輝度レーザであるディスクレーザおよびファイバー レーザは, 高出力でビーム品質が優れるため, キーホール生 成に必要とされるパワー密度 $\left(50 \mathrm{~kW} / \mathrm{mm}^{2} \text { 以上) }\right)^{1}$ が入射レー ザ方向に対し広範囲に実現でき, 厚板のレーザ溶接熱源とし て期待される。また, 減圧䨌囲気下におけるレーザ溶接は溶 达み深さが改善させることが報告されている ${ }^{2-5}$. 炭酸ガス レーザを用いたステンレス鋼 SUS304 の溶接では, $13 \mathrm{kPa}$ 減 圧䨌囲気下, レーザ出力 $20 \mathrm{~kW}$, 溶接速度 $5 \mathrm{~mm} / \mathrm{s}$ の条件で, 大気圧下の 2.5 倍程度に相当する $45 \mathrm{~mm}$ 溶込み深さが得ら

*受付日 平成24年 8 月23日 受理日 平成25年 2 月26日 平 成22年度秋季全国大会で発表

**学生員 大阪大学工学研究科 (現 日立造船(株) Student member, Graaduate School of Engineering, Osaka University (Present Address Hitachi Zosen Corporation)

***正員 大阪大学接合科学研究所 Member, Joining and Welding Research Institute, Osaka University

****正員 大阪大学工学研究科 Member, Graduate School of Engineering, Osaka University

*****正 員 阿南工業高等専門学校 Member, Anan National College of Technology
れている21.また, 溶融池の安定性およびレーザ誘起プルーム が溶接結果に影響することが報告されている ${ }^{3)}$. Y $\mathrm{YG}$ （Ytterbium aluminum garnet） レーザ溶接の報告では， $0.4 \mathrm{kPa}$ の減圧䨌囲気下, $3 \mathrm{~kW} レ$ レ゙出力の条件で, SUS304 ステン レス鋼は大気圧下の 1.3 倍, A5083アルミニウム合金は 2.8 倍に相当する溶込み深さが得られ, ポロシティの低減が確認 されている4). しかしながら, レーザの種類, 材料, 減圧䨌囲 気，溶接条件によって溶込み深さの改善に違いがあり，減圧 雲囲気が溶达みおよび溶接現象に対する影響について十分 に明らかにされていないのが現状である。

本研究では, 高出力で優れたビーム品質 BPP (Beam parameter product） $8 \mathrm{~mm} * \mathrm{mrad}$ を有する最大出力 $16 \mathrm{~kW}$ のデイス クレーザ (波長：1030 nm) を用い, $0.1 \mathrm{kPa}$ の減圧䨌囲気から 大気圧 $(101 \mathrm{kPa})$ に制御された空間おいて，ステンレス鋼 SUS304 およびアルミニウム合金A5052 の厚板に対し， $17 \mathrm{~mm} / \mathrm{s}$ 溶接速度でメルトラン溶接を行い, 得られた溶込み 深さおよび形状を調べた。また, 各減圧䨌囲気でのレーザ誘 起プルームの状態観察および, プルーム通過で可視光プロー ブレーザが屈折される角度計測を行い, プルームによる光の 伝搬特性への影響について評価した。さらに, 各減圧䨌囲気 下におけるキーホールロおよびその周囲の溶融池挙動を高 速度ビデオで観察して溶接現象を明らかにし, 減圧雲囲気と 溶込みとの関係について検討した。 


\section{2. 供試材，実験装置および実験方法}

供試材は，オーステナイト系ステンレス鋼 SUS304 および アルミニウム合金 A5052 で，サイズは $80 \times 50 \times 150 \mathrm{~mm}$ であ り，各金属の化学組成についてまとめたものを Table 1 に示

Table 1 Chemical compositions of stainless steel and aluminum alloy used.

(a) Type 304 stainless steel (mass \%)

\begin{tabular}{|c|c|c|c|c|c|c|c|}
\hline $\mathrm{C}$ & $\mathrm{Si}$ & $\mathrm{Mn}$ & $\mathrm{P}$ & $\mathrm{S}$ & $\mathrm{Ni}$ & $\mathrm{Cr}$ & $\mathrm{Fe}$ \\
\hline 0.04 & 0.5 & 0.9 & 0.03 & 0.001 & 8.1 & 18.2 & Bal. \\
\hline
\end{tabular}

(b) A5052 aluminum alloy (mass \%)

\begin{tabular}{|c|c|c|c|c|c|c|}
\hline $\mathrm{Si}$ & $\mathrm{Fe}$ & $\mathrm{Cu}$ & $\mathrm{Mn}$ & $\mathrm{Mg}$ & $\mathrm{Cr}$ & $\mathrm{Al}$ \\
\hline 0.1 & 0.26 & 0.02 & 0.05 & 2.4 & 0.22 & Bal. \\
\hline
\end{tabular}

す. 本研究で使用したレーザ発振器は, 最大出力 $16 \mathrm{~kW}$ の連 続発振型のディスクレーザ装置である. 溶接状況を模式図的 に Fig. 1 に示す.レーザ光は, 発振器からコア径 $\phi 0.2 \mathrm{~mm}$ の ファイバーによって伝送され，焦点距離 $1000 \mathrm{~mm}$ のレンズ で，アクリル製のチャンバー内の供試材の表面に集光した。 ステンレス鋼では，垂直にレーザ，高反射材であるアルミニ ウム合金では，レーザ戻り光防止のため10度傾けてレーザを 照射し, レーザ出力 $16 \mathrm{~kW}$, 溶接速度 $17 \mathrm{~mm} / \mathrm{s}$, 隇圧雲囲気 0.1 , 1，10，30，50，70，101 kPa下でメルトラン溶接を実施した. 供試材表面は焦点位置に置かれ, 入射レーザは, Fig. 2 に示す ような集光特性および焦点位置でのビームプロファイルを 有し，レーザスポット径は $\phi 0.5 \mathrm{~mm}$ で，ガウス分布と仮定し た場合のピークパワー密度は最大 $160 \mathrm{~kW} / \mathrm{mm}^{2}$ である。減圧 雾囲気下の実験では，チャンバー内部を所定の圧力にするた め，排気速度 $3.5 \mathrm{~g} / \mathrm{s}$ の 2 基打よび $11 \mathrm{~g} / \mathrm{s}$ の 1 基のロータリー

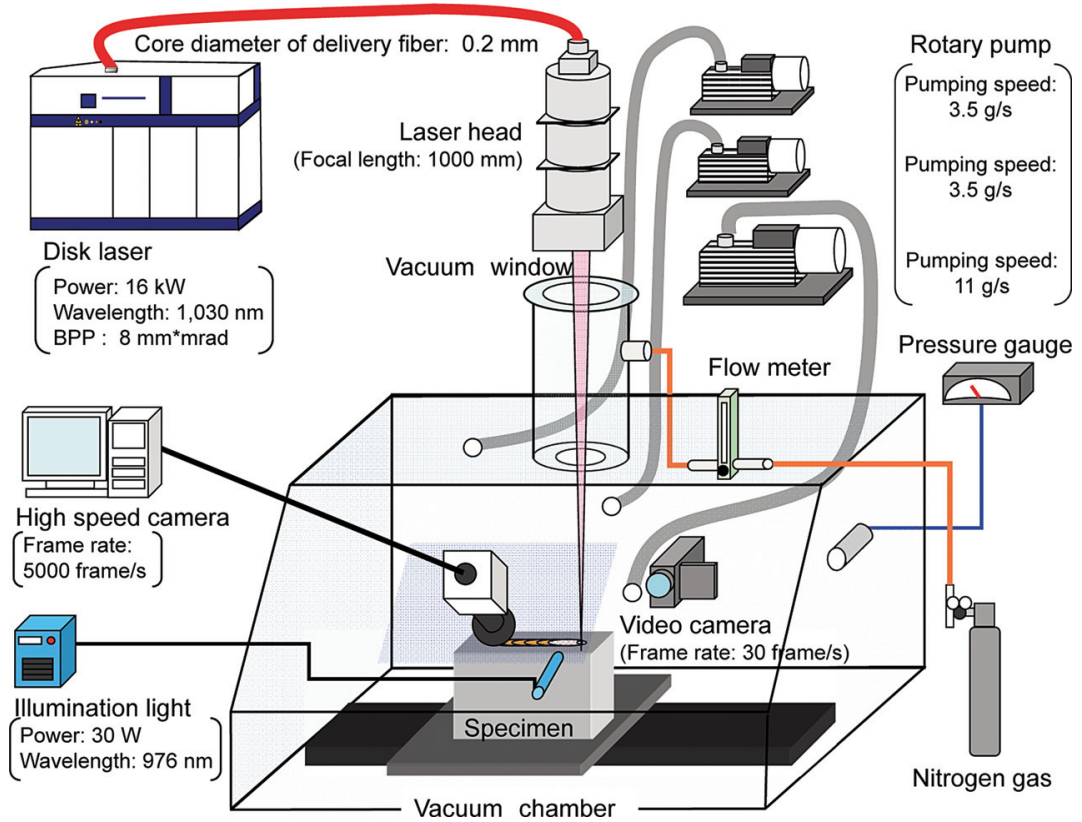

Fig. 1 Schematic experimental setup for disk laser welding under reduced-pressure atmosphere.

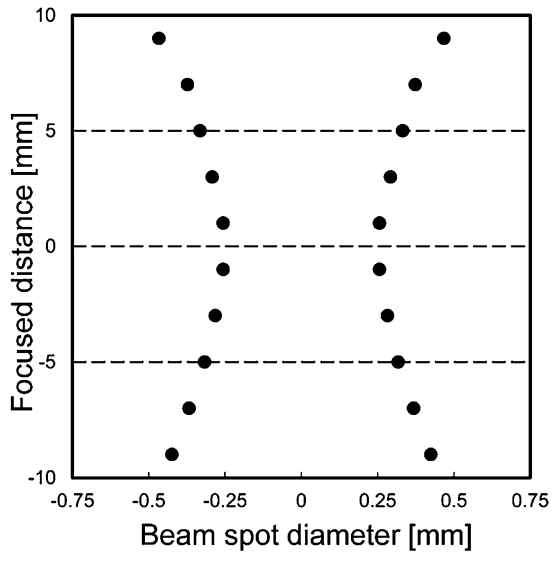

(a) Focusing feature of incident beam

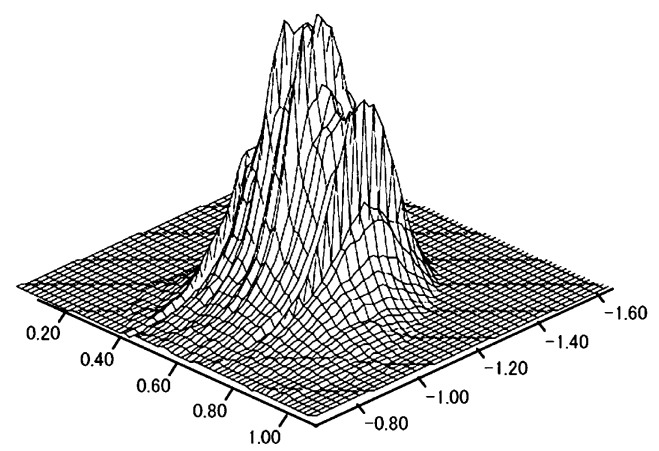

(b) Beam mode profile at focus position

Fig. 2 Focusing feature and beam mode profile at focus position. 
ポンプを使用し, $0.03 \mathrm{kPa}$ 程度まで減圧後, 窒素ガスを導入 し，所定の減圧雲囲気に制御した。なお，入射レーザ光が通 過する保護ガラスに,レーザ照射による供試材からの蒸発金 属が付着するのを防ぐため, 保護ガラスをチャンバー天井に 高さ $500 \mathrm{~mm}$ を超える煙突部に設置した. また，保護ガラス の下部にシールドガスの導入口があり, 蒸発金属の付着を妨 げる方向に導入ガスの流れを設計している. $101 \mathrm{kPa}$ の大気 圧下での実験では, 供試材をチャンバーの外に出し, シール ドガスとして窒素を溶接方向後方より45度の角度で, $16 \mathrm{~mm}$ 径のサイドノズルを用いて $0.6 \mathrm{~g} / \mathrm{s}$ で供給し, メルトラン溶接 を行った. 各溶接条件でのビード幅及び溶込み深さを調べる ために, 溶接長 $120 \mathrm{~mm}$ の溶接ビード中央部および中央部か ら前後 $20 \mathrm{~mm}$ 程度離れた位置の 3 断面においてビード形状 を測定し, 平均值を求めた。

各溶接条件でのプルームの発生状況を観察するため, デジ タルハイビジョンカメラを用い，プルームを溶融池側面方向 から $30 \mathrm{frames} / \mathrm{s}$ で撮影した。 また, Fig. 3 に示すように, 最大 出力 $200 \mathrm{~mW}$ の連続発振型半導体励起固体レーザ（波長： $532 \mathrm{~nm}$, スポット径： $1.5 \mathrm{~mm})$ をプローブレーザとして, 水平 方向からプルームを通過させ，プルームから $3.5 \mathrm{~m}$ 離れた位 置に設置したスクリーン上に照射し，スクリーン上のプロー ブレーザのスポット位置を，高速度ビデオカメラを用いて $1000 \mathrm{frames} / \mathrm{s}$ で観察した. そして, スクリーン上のスポット 位置に時間変化から, 減圧雲囲気下のプルームによるプロー ブレーザの屈折挙動を定量的に評価した。具体的には, レー ザ照射開始から $50 \mathrm{~ms}$ 毎の 140 駒の画像においてスポット の輝度重心位置を求め, 屈折の方向とともに, 原点からの距 離をプルームとスクリーン間の距離で除したプローブレー ザの屈折角 $\theta$ を求めた.

各溶接時のキーホール口および溶融池の挙動を観察する ため, 高速度ビデオを用いて, 溶融池表面を 5000 frames/s で 撮影し, 溶融池表面の挙動と溶込み深さとの関係について検 討した。なお，観察には，照明光源として半導体レーザ（最

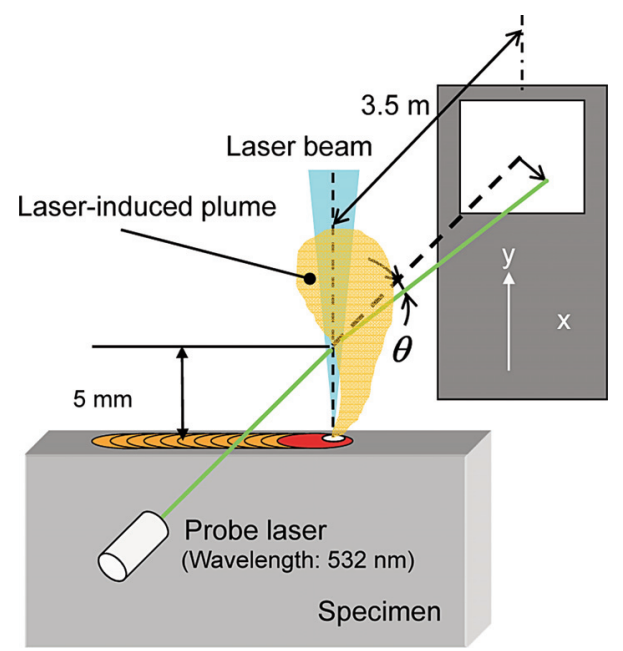

Fig. 3 Schematic experimental set-up for measurement of refraction angle in probe laser beam caused by laser-induced plume during welding.
大出力： $30 \mathrm{~W}$ ，波長：976 nm）を用い，干渉フィルター（中

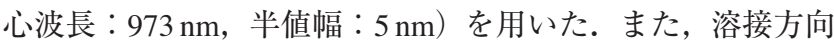
のキーホール平均口径およびキーホール中心位置での平均 溶融幅として，レーザ照射開始から $2.5 \mathrm{~s}$ までの $50 \mathrm{~ms}$ 毎に, キーホールおよび溶融池が明瞭に観察できた20駒の画像に ついての平均值を採用した。

\section{3. 実験結果および考察}

\section{1 減圧雰囲気下におけるステンレス鋼とアルミニウム 合金の溶込み}

$0.1 \mathrm{kPa}$ の減圧䨌囲気から大気圧までの様々な圧力下にお いて, 供試材表面をデイスクレーザビームの焦点位置に設置 し, $16 \mathrm{~kW}$ 出力, $17 \mathrm{~mm} / \mathrm{s}$ 溶接速度で，メルトラン溶接を実施 し，部分溶达み深さについて調査した。

ステンレス鋼 SUS304 に対し, $0.1,10,50,101 \mathrm{kPa}$ 圧力下で 得られた典型的なビード外観と溶込み断面の写真を Fig. 4 に示す。Fig. 4 が示すように，ビード幅は $101 \mathrm{kPa}$ から $0.1 \mathrm{KPa}$ に減圧するに伴い, $6.1 \mathrm{~mm}$ から狭くなり，1.7 $\mathrm{mm}$ と なり，ハンピングビードが形成された.なお，101 kPaのビー ド幅が $50 \mathrm{kPa}$ よりも狭いのは，酸化状況から雾囲気中の酸 素の影響が推察される. 溶込み深さは, 雲囲気の減圧に伴い,

\begin{tabular}{|c|c|c|c|c|}
\hline Pressure [kPa] & 101 & 50 & 10 & 0.1 \\
\hline Bead surface & $\therefore 0^{\circ}$ & & & \\
\hline $5 \mathrm{~mm}$ & 68 & & & \\
\hline Cross section & & & & \\
\hline $10 \mathrm{~mm}$ & & & & \\
\hline Bead width [mm] & 6.1 & 6.5 & 3.4 & 1.7 \\
\hline Penetration [mm] & 15 & 19 & 26 & 26 \\
\hline
\end{tabular}

Fig. 4 Surface appearance and cross section of weld bead obtained in Type 304 stainless steel plates under each reduced pressure.

\begin{tabular}{|r|c|c|c|c|}
\hline Pressure [kPa] & 101 & 50 & 10 & 0.1 \\
\hline Bead surface & & & & \\
$5 \mathrm{~mm} \mapsto$ & & & & \\
\hline $\begin{array}{r}10 \mathrm{~mm} \\
\text { Cross section } \\
10 \mathrm{~mm}\end{array}$ & & & & \\
$\qquad$ & & & \\
\hline Bead width [mm] & 12 & 8.9 & 8.5 & 5 \\
\hline Penetration [mm] & 14 & 22 & 23 & 19 \\
\hline
\end{tabular}

Fig. 5 Surface appearance and cross section of A5052 weld bead under each reduced pressure. 


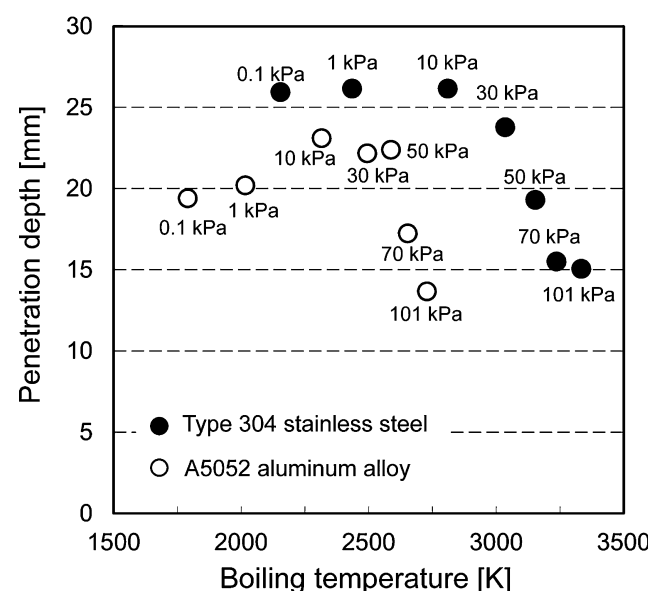

Fig. 6 Weld penetration depth as a function of boiling temperature calculated on the basis of reduced-pressure atmosphere.

大気圧下での $15 \mathrm{~mm}$ から増加し, $10 \mathrm{kPa} て ゙ ~ 26 \mathrm{~mm}$ 最大溶込 みに達し, 大気圧下の溶込みと比較して，1.7 倍となった。し

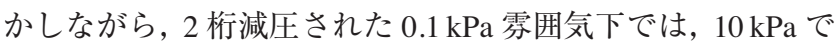
の溶込みと比べ，顕著な深さの増加がないこともわかった。

アルミニウム合金 A5052 に対し, 各雲囲気圧力下で得ら れたビード外観と溶込み断面の写真を Fig. 4 と同様に Fig. 5 に示す. 溶接ビード幅は, 圧力の低下に伴い細くなり, $0.1 \mathrm{kPa}$ では $5 \mathrm{~mm}$ となり, ステンレス鋼よりも 2.9 倍程度太く, ハン ピングビードが形成されないことが確認された。溶込み深さ は, 雾囲気の減圧に伴い, 大気圧下での深さ $14 \mathrm{~mm}$ から増加 し, $10 \mathrm{kPa}$ で最大深さ $23 \mathrm{~mm}$ となり, 大気圧下と比較して 1.6 倍となった。しかしながら， $0.1 \mathrm{kPa}$ で得られた溶込み深さ は，最大深さよりも減少し， $19 \mathrm{~mm}$ となった。また，溶接欠 陥ポロシティに関しては， $50 \mathrm{kPa}$ 以上の圧力では存在した が, $10 \mathrm{kPa}$ 以下では確認できなかった。

雾囲気が減圧されると, ステンレス鋼拈よびアルニミウム 合金の蒸気圧が低下し, 沸点が低くなるのでキーホールの生 成温度が下がり, 媣溶达み溶接に有効であると考えられる。 純鉄と純アルミニウムの蒸気圧の既存デー夕わを基に沸点 を算出し, 沸点と得られた溶达み深さとの比較を行った。比 較結果を Fig. 6 に示す. 両材料とも, $10 \mathrm{kPa}$ までの圧力では, 沸点の減少に伴い溶込みが増加し，10 kPa で最大溶込みに 達成し, 沸点の低下が溶込み深さの増加に影響を与えている

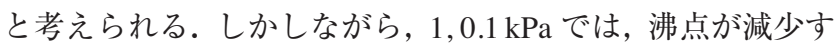
るにもかかわらず，ステンレス鋼は溶达みの改善が見られ ず，アルミニウム合金は溶込みが減少し，材料による違いが 存在した.

\section{2 減圧雾囲気下におけるレーザ誘起プルーム}

減圧雲囲気がレーザ誘起プルームおよび溶接結果に影響 するとの報告 ${ }^{3}$ があり，0.1，10，50,101 kPa 雲囲気圧力で発 生するステンレス鋼 SUS304 およびアルミニウム合金 A5052 のプルームの高速度観察を行った。溶接条件は 3.1 節 と同様である. ステンレス鋼プルームの観察結果を Fig. 7 に

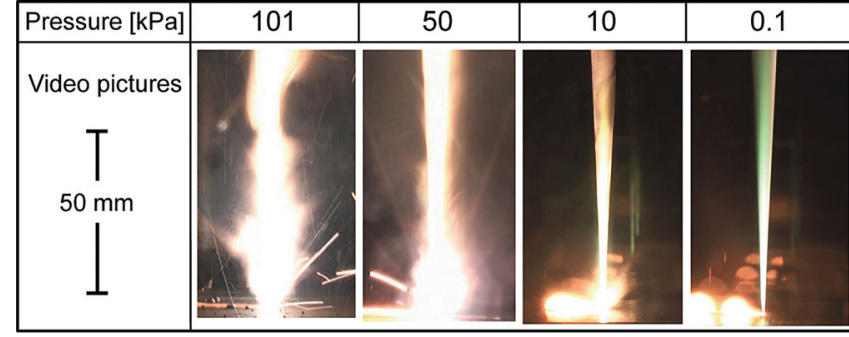

Fig. 7 Typical video picture of SUS304 laser-induced plume observed under each reduced pressure.

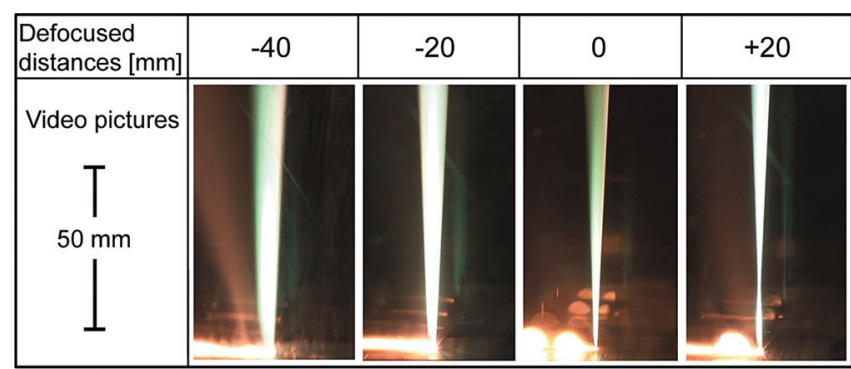

Fig. 8 Observation picture of reduced-pressure SUS304 plume at each defocused distance.

示す．各圧力下でプルームは大きく異なった． $101 \mathrm{kPa}$ 下で は, 大量のスパッ夕を伴って，羽のような形状の一般的なプ ルーム発光が観察された。 $50 \mathrm{kPa}$ では，大気圧下より形状が 小さいプルーム発光が確認された。 $10 \mathrm{kPa}$ になると, 101 およ び $50 \mathrm{kPa}$ で観測されたプルーム発光はレーザ照射部付近に 限定され，照射部上空には入射レーザ軌跡のような発光が観

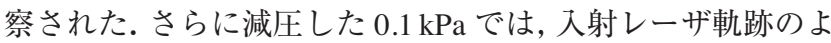
うな発光が明膫に観察された。

ここで, 観測された入射レーザ軌跡のような発光について 検討を行う。入射レーザ軌跡のような発光形状は，入射レー ザの集光状態（Fig. 2 (a) から算出した集光角：24度）と類似 した幾何的な形状をしていたので， $0.1 \mathrm{kPa}$ 隇圧雲囲気下に おいて, 焦点位置および-40, -20, +20 mm 焦点はずし距離で プルームの観察を行った。観察結果を Fig. 8 に示す.な扔, 供 試材表面を原点とし，焦点位置が集光レンズに近づく方向を 正方向とする。+20 mm 焦点はずし距離では, 供試材表面から 上空 $20 \mathrm{~mm}$ の位置（入射レーザの焦点位置）で，入射レーザ 軌跡のような発光のくびれが観測された. 各焦点はずし距離 がマイナス方向に変化するに伴い, 発光くびれは供試材内部 に隠れ，供試材表面での発光部が太くなって，想定される入 射レーザの軌跡 (集光角) と幾何学的に一致した。よって, 入 射レーザの軌跡に沿った発光部には青白く撮影されている 部分もあることから，単に散乱されたレーザが撮影されてい るとは考えられない。むしろプルームを構成する蒸発金属 が, 入射レーザの光軸上で加熱されて発光していると推察さ れ，減圧下のプルームに関する新しい知見と考える。

各雲囲気でステンレス鋼を溶接した場合に発生したプルー ムを透過させたプローブレーザの，スクリーン上のスポット 


\begin{tabular}{|c|c|c|c|c|c|}
\hline \multirow{2}{*}{$\begin{array}{c}\text { Pressure } \\
\text { [kPa] }\end{array}$} & \multicolumn{5}{|c|}{ Time [s] } \\
\hline & 0 & 1.5 & 3.0 & 4.5 & 6.0 \\
\hline 101 & & & & & \\
\hline 50 & & & & & \\
\hline 10 & & & & & \\
\hline 0.1 & & & & & \\
\hline
\end{tabular}

Fig. 9 High-speed video picture of probe laser spot passing through SUS304 plume under each reduced pressure.

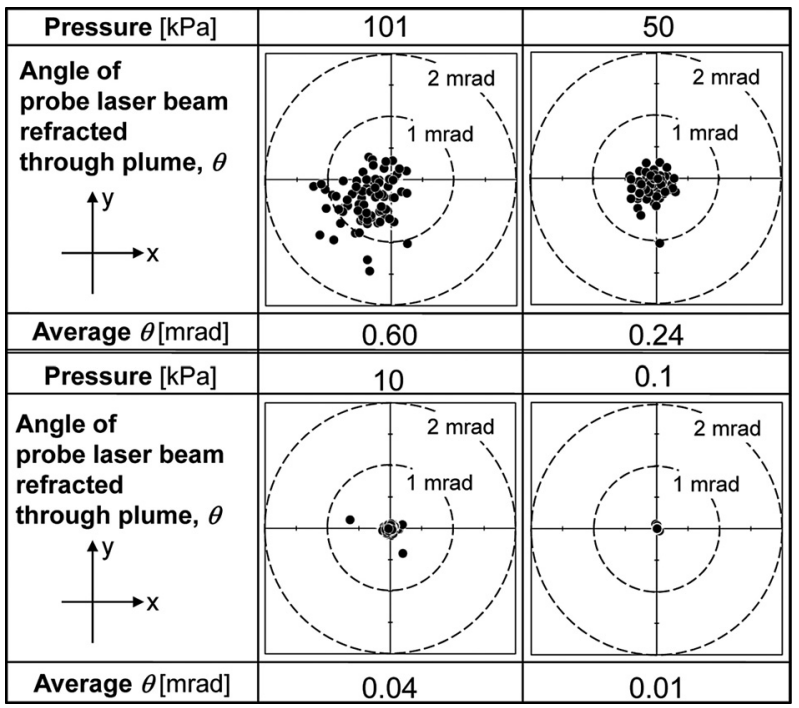

Fig. 10 Effect of reduced-pressure atmosphere on refraction angle of probe laser beam caused by laser-induced plume at welding in SUS304.

の観察結果を Fig. 9 に示す. $101 \mathrm{kPa}$ では, スポット移動およ び形状変化が観測され，101 kPa から減圧されるに従い，又 ポット移動量および形状変化は低減された. 最も減圧された $0.1 \mathrm{kPa}$ では，レーザ照射前と比較してスポット移動はほと んどなく，スポットの形状変化も確認されなかった。また， Fig. 9 の観察結果より，レーザの屈折方向と屈折角 $\theta$ を計算 した結果を Fig. 10 に示す. $101 \mathrm{kPa}$ と比較し, 1 桁以上小さな 值となった。これは，プルームがプローブレーザの伝搬に与 える影響が弱くなったことを意味している.

アルミニウム合金 A5052 について，高速度ビデオを用い たプルームの観察とプローブレーザの屈折状態の観察を行 つた. 観察結果を Fig. 9 と同様に Fig. 11 に示す. ステンレス 鋼と同様に, 各減圧䨌囲気下でプルーム状態は大きく恋化し た. $101 \mathrm{kPa}$ 下では, 大量のスパッタを伴った青白いプルーム

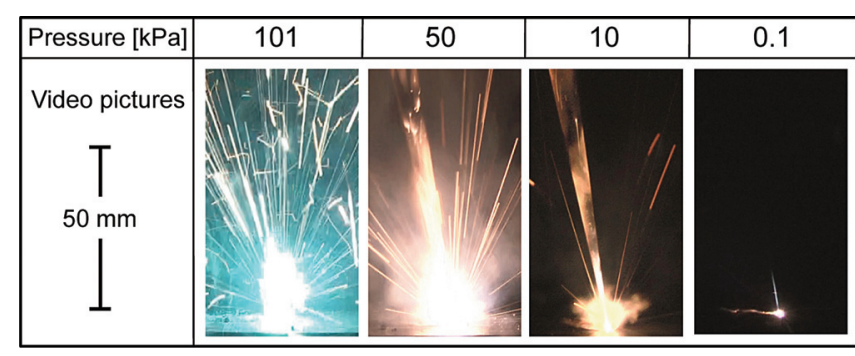

Fig. 11 Typical observation picture of A5052 plume under each reduced pressure.

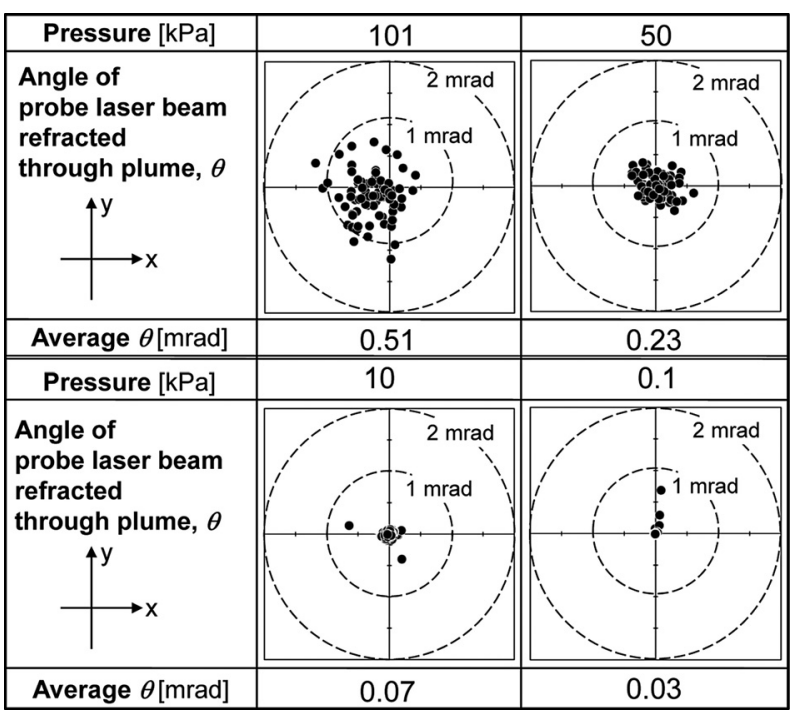

Fig. 12 Effect of reduced-pressure atmosphere on A5052 plume.

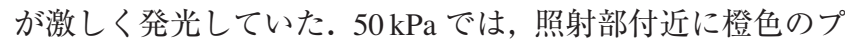
ルームが観測され，照射部上空には，入射レーザ軌跡のよう な発光が観察された。 $10 \mathrm{kPa}$ になると, 照射部付近の発光が 弱くなるが，入射レーザ軌跡のような発光は確認された。さ らに $0.1 \mathrm{kPa}$ では，白色のプルームの発光がレーザ照射部付 近でわずかに観察された.プローブレーザの屈折角 $\theta$ の計測 結果を Fig. 10 と同様, Fig. 12 に示す. A5052 では SUS304 と 同様に, 減圧に伴い屈折が改善され, 安定していることがわ かった.プルームの発光がほとんど観察されない $0.1 \mathrm{kPa}$ 下 の $\theta$ の平均值は $0.03 \mathrm{mrad}$ であり, $101 \mathrm{kPa}$ と比較し 1 桁以上 優れた值が得られ，プルームとプローブレーザの相互作用が 小さいことが確認された.

\section{3 減圧雰囲気下におけるキーホールロおよび溶融池}

深溶込みには，レーザが安定してキーホールへ導光される ことが必要で，キーホール口の挙動は重要である，各雲囲気 圧力でのキーホール口および溶融池の高速度ビデオによる 観察を行った。ステンレス鋼の典型的な観察結果を Fig.13に 示す. $101 \mathrm{kPa}$ では, キーホール平均口径は $1.2 \mathrm{~mm}$ で, 平均溶 融池幅は $1.8 \mathrm{~mm}$ となり, 溶融池表面には金属酸化皮膜が確 認でき, キーホール口周辺で溶融池表面の波打つような変動 が観察された。雲囲気の減圧に伴って，キーホール口径は小 


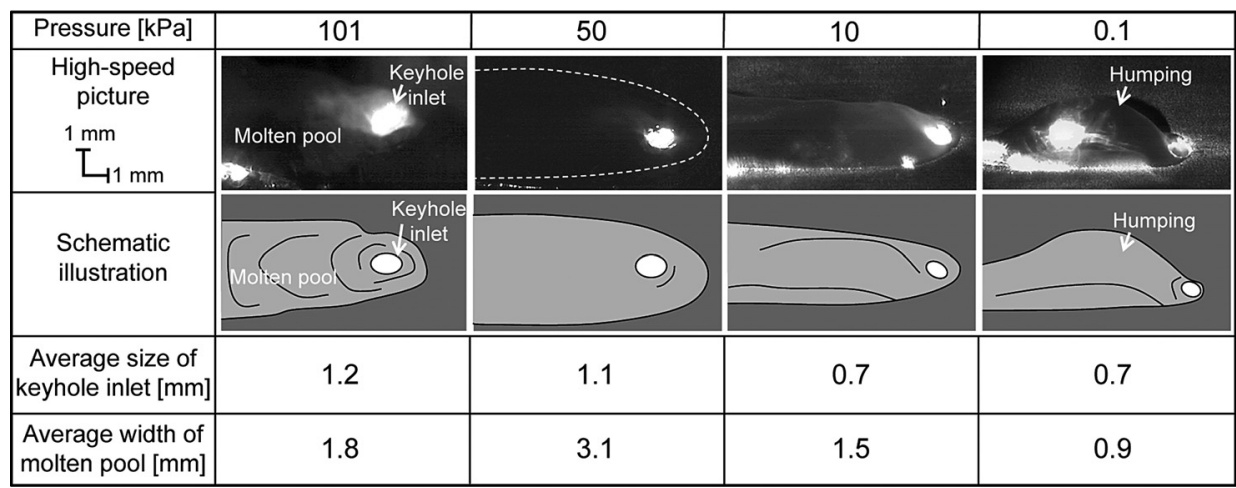

Fig. 13 High-speed video picture of keyhole inlet and molten pool in Type 304 stainless steel weld observed under each reduced pressure.

\begin{tabular}{|c|c|c|c|c|}
\hline Pressure $[\mathrm{kPa}]$ & 101 & 50 & 10 & 0.1 \\
\hline $\begin{array}{l}\text { High-speed } \\
\text { picture } \\
1 \mathrm{~mm} \\
\mathrm{~L}_{1} 1 \mathrm{~mm}\end{array}$ & Molten pool Keyhole & & & 5 \\
\hline $\begin{array}{l}\text { Schematic } \\
\text { illustration }\end{array}$ & & & & \\
\hline $\begin{array}{c}\text { Average size of } \\
\text { keyhole inlet [mm] }\end{array}$ & 0.9 & 1.4 & 1 & 3.9 \\
\hline $\begin{array}{l}\text { Average width of } \\
\text { molten pool }[\mathrm{mm}]\end{array}$ & 5.6 & 3.4 & 3.1 & 1.3 \\
\hline
\end{tabular}

Fig. 14 High-speed observation picture of keyhole inlet and molten pool in A5052 welds under each reduced pressure.

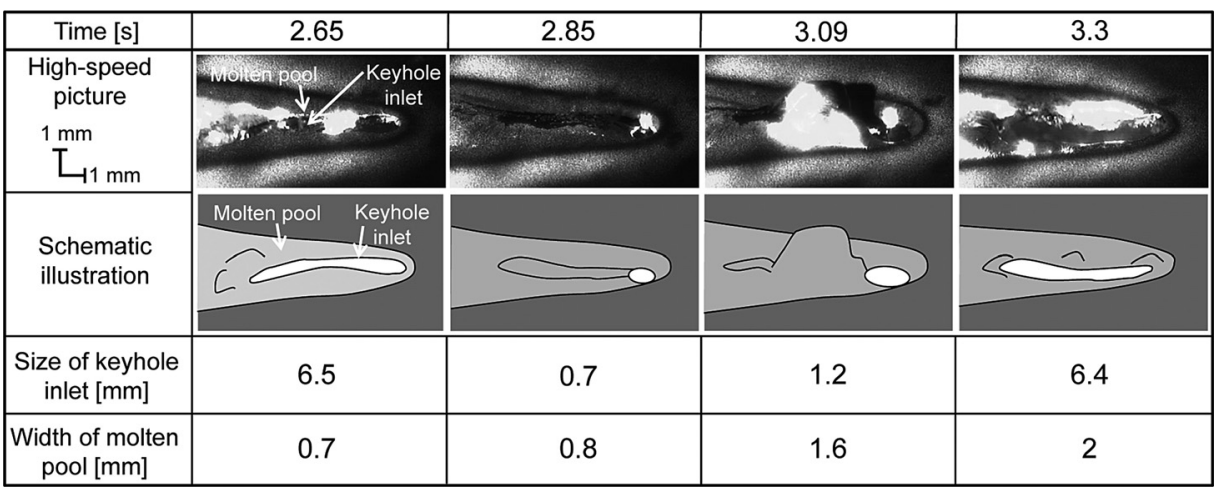

Fig. 15 Unstable behavior of keyhole inlet and molten pool in A5052 weld obtained at $0.1 \mathrm{kPa}$.

さくなり，溶融池表面の挙動は安定し，溶融池幅が狭くなっ た. $10 \mathrm{kPa}$ でキーホール平均口径は $0.7 \mathrm{~mm}$ に至り, 入射レー ザのスポット $0.5 \mathrm{~mm}$ と比較して 1.4 倍の值となった。ささらに 減圧された $0.1 \mathrm{kPa}$ では, キーホール口径の変化は見られない が, 平均溶融池幅は大気圧䨌囲気下の約 $1 / 2$ にまで減少し, 溶 融池後方にハンピングビードが形成されていることが確認 された.ステンレス鋼におけるレーザ溶接時のハンピング形 成の原因および防止法の研究成果 ${ }^{8}$ を踏まえると, ハンピン グの原因は溶融池幅が狭くなった結果, 融液の溶融池後方へ の流速が速くなり, 溶融池後方に融液が過剩に残留したため と推察される。

次に，アルミニウム合金におけるキーホール口および溶融
池の観察結果を Fig. 13 と同様に Fig. 14 に示す. $101 \mathrm{kPa}$ 下で は, キーホール平均口径は, 入射レーザスポットと比べ 1.8 倍 となる $0.9 \mathrm{~mm}$ であり, キーホール口付近まで溶融池表面が金 属酸化皮膜に覆われ, 大きく盛り上がっていた.需囲気圧力が $101 \mathrm{kPa}$ から $10 \mathrm{kPa}$ まで減圧されるに伴い, キーホール平均口 径は $0.9 \mathrm{~mm}$ から $1.4 \mathrm{~mm}$ までの值を推移し，ステンレス鋼と は異なる傾向を示した。ささらに， $0.1 \mathrm{kPa}$ では，キーホール平 均口径は $3.9 \mathrm{~mm}$ に増加した。一方, 平均溶融池幅は, ステン レス鋼と同様に減圧に伴い，101 kPa の $5.6 \mathrm{~mm}$ から $0.1 \mathrm{kPa}$ の $1.3 \mathrm{~mm}$ まで減少した.そこで, 特異な現象の生じた $0.1 \mathrm{kPa}$ で のキーホール口径の増加について, 高速度ビデオ観察結果を 基に時間変化の詳細を観察した. 観察結果を Fig. 15 に示す. 
Table 2 Effect of reduced-pressure atmosphere on keyhole inlet and molten pool in Type 304 stainless steel weld.

\begin{tabular}{|c|c|c|c|c|c|}
\hline \multirow{2}{*}{ Pressure [kPa] } & \multirow{2}{*}{$\begin{array}{c}\text { Penetration } \\
\text { depth [mm] }\end{array}$} & \multicolumn{2}{|c|}{ Size of keyhole inlet [mm] } & \multicolumn{2}{c|}{ Width of molten pool [mm] } \\
\cline { 3 - 6 } & 15 & Average & Standard deviation & Average & Standard deviation \\
\hline 101 & 1.2 & 0.2 & 1.8 & 0.3 \\
\hline 70 & 16 & 1.1 & 0.1 & 4.1 & 0.2 \\
\hline 50 & 19 & 1.1 & 0.1 & 3.1 & 0.2 \\
\hline 30 & 23 & 0.8 & 0.09 & 2.7 & 0.1 \\
\hline 10 & 26 & 0.7 & 0.07 & 1.5 & 0.1 \\
\hline 1 & 26 & 0.7 & 0.05 & 1 & 0.03 \\
\hline 0.1 & 26 & 0.7 & 0.08 & 0.9 & 0.06 \\
\hline
\end{tabular}

Table 3 Effect of reduced-pressure atmosphere on keyhole inlet and molten pool in A5052 aluminum alloy weld.

\begin{tabular}{|c|c|c|c|c|c|}
\hline \multirow{2}{*}{ Pressure [kPa] } & \multirow{2}{*}{$\begin{array}{l}\text { Penetration } \\
\text { depth }[\mathrm{mm}]\end{array}$} & \multicolumn{2}{|c|}{ Size of keyhole inlet $[\mathrm{mm}]$} & \multicolumn{2}{c|}{ Width of molten pool [mm] } \\
\cline { 3 - 6 } & 14 & Average & Standard deviation & Average & Standard deviation \\
\hline 101 & 14 & 0.8 & 0.2 & 5.6 & 0.3 \\
\hline 70 & 17 & 1.3 & 0.4 & 4.1 & 0.5 \\
\hline 50 & 22 & 1.4 & 0.4 & 3.5 & 0.4 \\
\hline 30 & 22 & 1.2 & 0.2 & 3.4 & 0.3 \\
\hline 10 & 23 & 1 & 0.2 & 3.1 & 0.2 \\
\hline 1 & 20 & 5.8 & 0.8 & 1.5 & 0.3 \\
\hline 0.1 & 19 & 3.9 & 2.8 & 1.3 & 0.6 \\
\hline
\end{tabular}

(101 kPa: Ambient pressure)

レーザ照射開始から $2.65 \mathrm{~s}$ 後では, 溶接方向に長く伸びた キーホール口が観察でき, 口径は $6.5 \mathrm{~mm}$ と大きな值であっ た. $2.85 \mathrm{~s}$ では, キーホール口は, 円形で $0.7 \mathrm{~mm}$ となり, キー ホール後方に金属酸化膜に覆われていない溶融池表面の箇所 を確認できた. $3.09 \mathrm{~s}$ ではキーホール口径が 1.7 倍程度に大型 化し, 後方部は盛り上がった. その後, $3.3 \mathrm{~s}$ では, 再び $2.65 \mathrm{~s}$ と同様な長く伸びたキーホールが形成された。一連のキー ホール口および周辺の溶融池表面の挙動から，プルームが 一時的に強くなり，金属酸化膜に覆われていないキーホー ル後方の溶融池表面を押し上げて盛り上がり, その後落込 み, 溶接方向に長く伸びたキーホール口が形成されたと考 えられる。こうしたキーホール口および溶融池の一連の挙 動は，溶接中全ての時間で観察された。

各雲囲気圧力における, キーホール口径, 溶融池幅, それ らの平均值と標準偏差について, ステンレス鋼とアルミニウ ム合金でまとめたものを Table 2 および Table 3 に示す。な お，溶达み深さも併記しておく. Table 2 が示すようにステン レス鋼溶接時のキーホール口は，䨌囲気圧力の $101 \mathrm{kPa}$ から $10 \mathrm{kPa}$ までは小径化し， $10 \mathrm{kPa}$ 以下では平均值 $0.7 \mathrm{~mm}$ と一 定になった，標準偏差も同様な傾向で, 減圧に伴い小さくな り, $10 \mathrm{kPa}$ 以下では, $101 \mathrm{kPa}$ に比べ 1 桁小さい值となった. ところで, 前節において $10 \mathrm{kPa}$ 以下ではプルームによるレー ザ屈折がごく小さいことを述べた. $10 \mathrm{kPa}$ 以下の䨌囲気圧力 でキーホール口が小型化し安定していることは, 入射レーザ がよく絞られた状態で, 安定してキーホール口を通過してい ることと対応していると推察される。 また，雾囲気圧力が $70 \mathrm{kPa}$ から $0.1 \mathrm{kPa}$ 低下するに伴い, 平均溶融池幅は $4.1 \mathrm{~mm}$ から $0.9 \mathrm{~mm}$ まで減少した. 標準偏差も減圧に伴い減少を示
しており，ステンレス鋼の溶接現象が減圧によって安定する と考えられた。一方，101 kPaでは，雲囲気圧力の増大にも関 わらず溶融池幅が $1.8 \mathrm{~mm}$ と, $70 \mathrm{kPa}$ に比較して狭くなった。 これは, 大気中の酸素が影響したものと推定される。溶融池 幅に関しては, $101 \mathrm{kPa}$ では酸素の影響で $1.8 \mathrm{~mm}$ と狭くなる と推察され，䨌囲気圧力が $70 \mathrm{kPa}$ から $0.1 \mathrm{kPa}$ 低下するに伴 い, $4.1 \mathrm{~mm}$ から $0.9 \mathrm{~mm}$ まで減少した。標準偏差も減圧に伴 い減少を示しており, ステンレス鋼の溶接現象が減圧によっ て安定することがわかった.

一方, Table 3 が示すようにアルミニウム合金では, キー ホール平均口径は, $101 \mathrm{kPa}$ から $10 \mathrm{kPa}$ までは, $0.8 \mathrm{~mm}$ から $1.4 \mathrm{~mm}$ までの值を推移し, 標準偏差は $0.2 \mathrm{~mm}$ から $0.4 \mathrm{~mm}$ で ステンレス鋼の傾向とは異なった.さらに, $1,0.1 \mathrm{kPa}$ 下では, Fig. 15 に示すようなキーホール口の変動により，平均口径 は, $101 \mathrm{kPa}$ 下の $0.8 \mathrm{~mm}$ から最大 $5.8 \mathrm{~mm}$ までに増加し, 標準 偏差も $0.2 \mathrm{~mm}$ から最大 $2.8 \mathrm{~mm}$ に達し, プロセスが不安定に なることが判明した.Fig. 6 に示したように,アルミニゥム合 金では $1,0.1 \mathrm{kPa}$ の雲囲気圧力下で沸点の減少に関わらず溶 込み深さが $10 \mathrm{kPa}$ に比較して減少したが，これはこのプロ セスの不安定性に起因する現象と考えられる. 溶融池幅に関 しては，ステンレス鋼と同様な減少傾向を示した.

以上，雲囲気の減圧に伴い供試材の沸点低下，レーザ誘起 プルームによるレーザ屈折能力の減少, キーホールロに導光 されることから，ステンレス鋼 SUS304 では $10,1,0.1 \mathrm{kPa}$ の 雲囲気圧力で, アルミニウム合金 A5052 では $10 \mathrm{kPa}$ で, 大気 圧での溶达みの 1.6 倍以上の最も深い溶达みが形成されたと 考えられる. 


\section{4. 結}

\section{言}

本研究では， $16 \mathrm{~kW}$ 高出力ディスクレーザを用い， $0.1 \mathrm{kPa}$ から $101 \mathrm{kPa}$ の雲囲気下において, ステンレス鋼 SUS304 お よびアルミニウム合金A5052の厚板に対し，溶接速度 $17 \mathrm{~mm} / \mathrm{s}$, 供試材表面が焦点位置である条件でメルトラン溶 接を行い, 得られた溶込み深さを調べた。 また, 各減圧䨌囲 気でのレーザ誘起プルームの観察およびレーザの屈折特性 を評価した。ささらに, 各減圧雲囲気下におけるキーホール口 および溶融池挙動を, 高速度ビデオで観察して溶融現象を明 らかにし, 深溶达みとの関係について検討を行った. 得られ た結果は以下の通りである。

1）ステンレス鋼 SUS304 の厚板に対する $16 \mathrm{~kW}$ 高出力レー

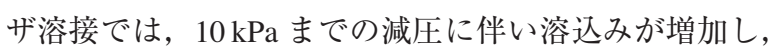

$10,1,0.1 \mathrm{kPa}$ の䨌囲気圧力で最大溶込み $26 \mathrm{~mm}$ に達成 し，大気圧下の溶込みと比較して，1.7 倍となった。

2）アルミニウム合金 $\mathrm{A} 5052$ の厚板に対する $16 \mathrm{~kW}$ 高出力 レーザ溶接では, $10 \mathrm{kPa}$ で最大溶込み $23 \mathrm{~mm}$ となり, 大気 圧下と比較しておよそ1.6倍となった。しかしながら，1 および $0.1 \mathrm{kPa}$ では, 溶込みが減少することが判明した。

3）純鉄と純アルミニウムの蒸気圧を基に算出した沸点と溶 込み深さとの比較により, 両材料とも, $10 \mathrm{kPa}$ 以上では, 沸点が減少することと溶込みが増加することとの関係が 示唆された. しかしながら, $1 \mathrm{kPa}$ 以下では, ステンレス 鋼は溶込みの改善は見られず，アルミニウム合金は溶込 みが減少し，材料による違いが存在した。

4）高速度ビデオによる観察およびプローブレーザによる屈 折測定によって，101 kPa から $0.1 \mathrm{kPa}$ までの䨌囲気では, 滅圧されることにより，ステンレス鋼およびアルニミウ ム合金のレーザ誘起プルームは，レーザを屈折させる能 力が低減することが明らかになった。

5）減圧䨌囲気下における入射レーザ軌跡のようなプルーム 発光について, プルームを構成する蒸発金属が, 入射レー ザの光軸上で加熱され発光していると推察され, 減圧雲 囲気下のプルームについての新しい知見が得られた。

6）ステンレス鋼のキーホール口は, 雲囲気圧力の $101 \mathrm{kPa}$ から $0.1 \mathrm{kPa}$ の減圧に伴い, $40 \%$ 程度小径化し, 標準偏差 も 1 桁小さくなり, 入射レーザはよく絞られた状態で, 安
定してキーホール口を通過していると考えられる。

7）アルミニウム合金のキーホール口は， $1,0.1 \mathrm{kPa}$ 下で, 平 均口径が $101 \mathrm{kPa}$ 下の $0.8 \mathrm{~mm}$ から最大 $5.8 \mathrm{~mm}$ までに増 加し, 標準偏差も $0.2 \mathrm{~mm}$ から最大 $2.8 \mathrm{~mm}$ に達し, プロセ スが不安定となった。プロセスの不安定性は溶达みを減 少させる要因と推察される.

8）雲囲気の減圧に伴い, 供試材の沸点低下, 誘起プルームに よるレーザ屈折能力の減少，キーホール口および溶融池 の安定化が, 入射レーザをよく絞られた状態で, キーホー ル口に安定して導光でき，結果としてステンレス鋼では $10 ， 1 ， 0.1 \mathrm{kPa}$ の䨌囲気圧力で，アルミニウム合金では， $10 \mathrm{kPa}$ で最も深い溶込みが形成されたと考えられる.

謝辞

本研究の一部は, 平成22年から平成24年まで採択された科 学研究補助金基盤研究 (C)「局所低真空下の高輝度レーザに よる高効率深溶込み溶接機構の解明」の一環として行った研 究であり，関係各位に感謝申し上げます。

\section{参 考 文 献}

1) T. Arai, M. Kutsuna and M. Miyamoto H. Kaneko:レーザー溶接加 工, Machinist, (1996), 4. (in Japanese)

2) T. Ishide, T. Ikeda, G. Takano, T. Hayashi, K. Matsuhiro and Y. Inaba: Basic study on high-power $\mathrm{CO} 2$ laser welding, Preprints of The National Meeting of J.W.S. 55 (1994), 32-33. (in Japanese)

3) T. Ishide, M. Mega and Y. Shimokusu: Fundamental Study on High-Power CO2 Laser Welding Technique, Mitsubishi Heavy Industries Technical Review, 32-2 (1995), 109-112. (in Japanese)

4) S. Katayama, Y. Kobayashi, M. Mizutani and A. Matsunawa: Effect of vacuum on penetration and defects in laser welding, J. Laser Appl., 13-5 (2001), 187-192.

5) Y. Arata, N. Abe and T. Oda: Fundamental Phenomena in High Power CO2 Laser (Repoert II) -Vacuum Laser WeldingTransactions of JWRI, 14-2 (1985), 17-22.

6) K. Mitani, Y. Suita, Y. Aiga S. Shobako, Y Tsukuda and N. Terajima: Butt Weld Experiments by Diode Laser Welding Process in Vacuum, Space Utiliz. Res., 24 (2008), 94-97. (in Japanese)

7) The Japan Institute of Metals: 改訂 3 版 金属データブック, Maruzen, (1995), 86-88. (in Japanese)

8) Y. Kawahito, M. Mizutani and S. Katayama: Defect Formation Mechanism and Reduction Procedure in $10 \mathrm{~kW}$ High Power Fiber Laser Welding of Stainless Steel, Q. J. Jpn. Weld. Soc., 26-3 (2008), 203-209. (in Japanese) 